\title{
Notes
}

\section{Interview with Martin Jay on Violence, Fundamentalism and Free Speech}

\section{Özgür Yaren}

Ankara University Faculty of Communication

yarenozgur@gmail.com

Right after the horrible attack to French satirical cartoon magazine Charlie Hebdo, I've come by with this simple but striking cartoon. At first sight, nothing seems funny about it. Its style is not grotesque. No funny stylization. Rather than a caricature, it reminds one, Frans Masereel's expressionist woodcut prints. Light and shadow balance is slightly in favor of shadows. And then, there comes the striking punch line coming from ISIS leader, a dark figure, almost entirely seems like a blot. In the context of a bloody campaign, countless massacres and gratification of sacrifice, death and violence, his wish of health seem absurd and surreal. Having this single cartoon as a starting point, I've interviewed with Prof. Martin Jay of UC Berkeley, a prominent historian on Critical Theory and a thinker. I've asked about violence, fundamentalism and free speech. Today a brief look on the hot debates around these topics is enough to realize the desperateness of the attempts to comprehend. Among all these rumble and dusty air, I do believe that Martin Jay can provide much required composed and calm attitude.

Q. How do you conceive this new wave of glorification of sacrifice, death and violence above every possible form of morality? Careless killings of civilians, children, cartoonists, journalists, reminding cold-blooded Nazi techniques and 
concentration camps... Why did life; both the victims and their own, lost its value for this Islamofascist groups? Where does this strong disconnectedness come from? Nihilism? Lumpen-proleteriat nature of the warriors?

A. A lot of people much smarter than you or me have been stumped by this question. Indifference to unintended "collateral damage" leaves victims just as dead as glorified sacrificial killing, so I would not entirely exempt the opponents of Islamofascism-if we can use that word to describe ISIS and their ilk-from some responsibility for the carnage in the world today. But there is indeed something very hard to understand about the reveling in slaughtering innocents that seems now to have infected some violent actors claiming to speak in the name of Islam. I have no doubt that they are a small minority and that their atrocities are lamented by the majority of followers of the Prophet. I'm glad to see that strong protests are finally being made by the latter against the hijacking of Islam by the fanatics, for we are dangerously close to a situation, especially in Europe, in which some sort of prolonged civilizational war might break out. Only if responsible Muslims vigorously restrain and ostracize those who employ terror in their name can we head off the counter-violence that is being generated on the radical right in France and elsewhere in Europe.

Q. In terms of religious rhetoric and sectarian war, do you see any resemblance between peasant revolts and ISIS $\mathcal{E}$ its derivations? Differences are obvious, latter one being a modern and global movement. But, how about the resemblances?

A. I am not a serious student of peasant revolts, so am loath to provide an answer beyond saying that it is unquestionably true that religious rhetoric - and indeed religiously inspired motivations_often accompany movements of social and political protest against existing authority and power. As a result, historians struggle to disentangle their multiple causes and sort out the reasons people who are normally docile, accepting their lot in life, rise up to challenge it. For those of us in the West with little real understanding of Islam and the Middle East, it would be very hazardous to draw easy parallels with peasant revolts closer to our own experience. As the cautionary example of Michel Foucault and the Iranian Revolution shows, it is easy to confuse hopes with sober analyses. 


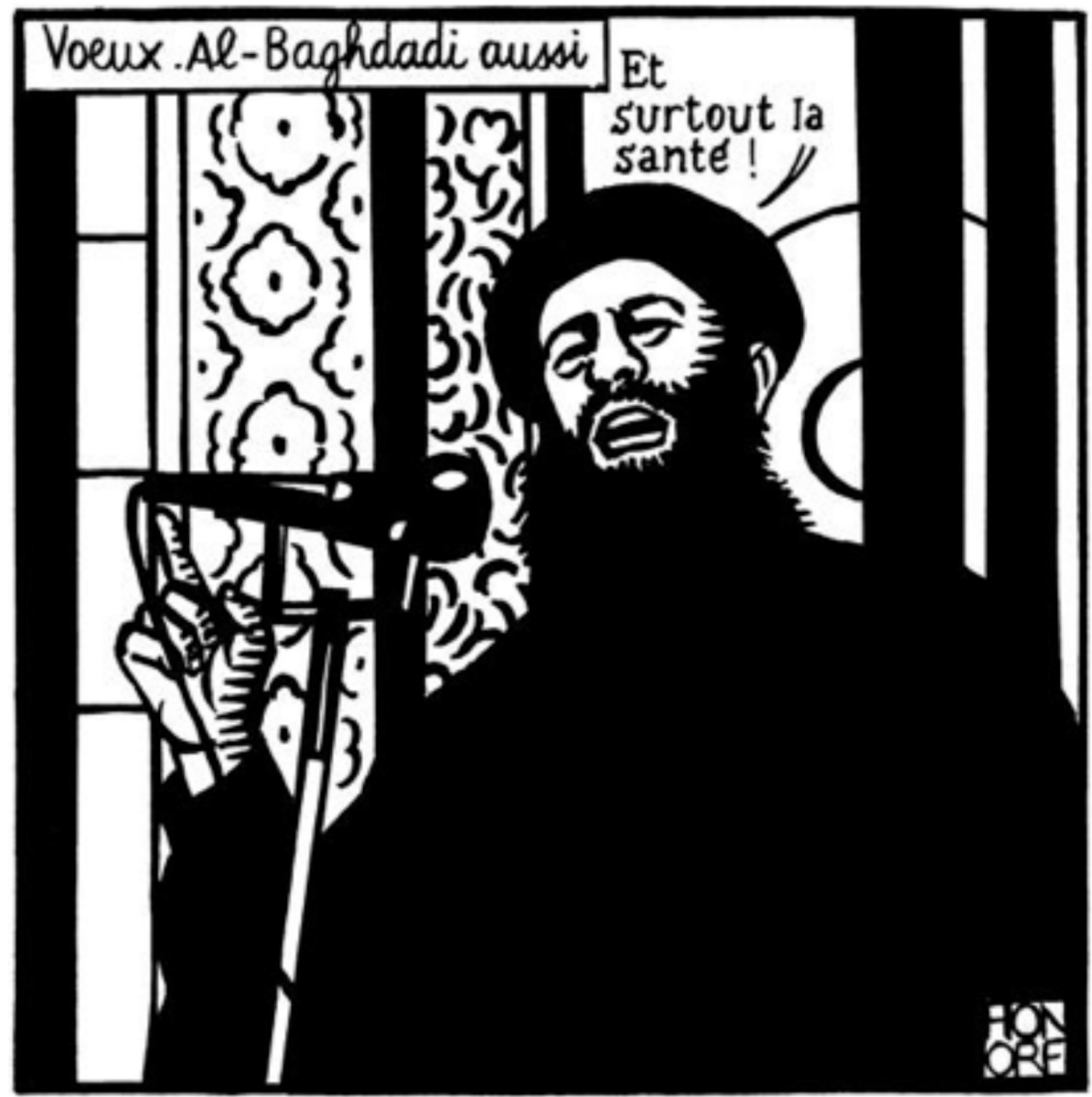

Q. Crisis of synchronicity, failure of synchronicity or resistance against it, is a traceable concept among critical theory thinkers. Adorno and particularly Ernst Bloch were dealing with non-contemporality. Would it be a helpful concept to understand this fundamental wave? How would be Bloch's reading of ISIS? How would you understand ISIS, Al-Qaida etc.'s reactionary stance and rhetoric of 'century of happiness' (prophet's times, a golden age narrative); regressive, nostalgic, nihilist or wish to return to 'prefigural traces' (what not really happened; but prefigured, to a desired state, recapturing cyphers of future redemption)?

A. The insight that historical time is "out of joint" and contains residues of a past that is not yet fully over and intimations of a future that is not yet-and may never be-born does, I think, help us make sense of the 
bewildering state of affairs in the world today. It allows us to see that despite the homogenizing effects of globalization, there is no temporal coherence in which everyone shares the same moment in a linear narrative or indeed even believes in the same narrative of change. Bloch's notion of non-synchronicity should not, however, be taken to mean that there is an underlying universal temporal development by which we can measure alleged "progressive" and "regressive" movements. As we learned the hard way with so-called "modernization" theory, it is always problematic to posit one society as advanced and others as trying to catch up. Grand narratives of, say, secularization or technological progress are harder to accept naively than they were before cogent post-modernist objections were raised to them. We now know that being temporally "out of joint" is far more likely than a universal chronological order in which everyone moves together into the future.

As for the way Bloch would read ISIS, I imagine he would be able to find faint ciphers of hope for a redemptive future in their ideology, which would help explain how they can commit such acts of brutality without apparent moral remorse. But rather than allow such an insight to provide some sort of excuse for their actions, it might be better to question the premise that utopian redemption is a valid goal, because no matter how pure their motives, the means they have chosen make it utterly impossible ever to realize their aims. And of course, the victims who have been caught in their fantasies of ultimate redemption cannot in any way be understood as serving any positive outcome whatsoever. There is no "cunning of reason" or religious theodicy that can be adduced to justify or dignify their utterly meaningless loss.

Q. Do you think, Bloch's take would be too ecumenical and forgiving in this case?

A. If Bloch's theory serves in any way as a justification or exoneration of their actions, it would be a disaster to invoke it. But if it helps us to understand how they may well justify those actions in their own minds, then it is a useful hermeneutic tool. His underlying assumption that there is an ontological yearning for a better future- a "not yet" that actually exists on some deeper level than mere human desires-seems to me, however, very dubious, because it can be used to glorify anything that seeks a utopian alternative to the present imperfect world. As a result, it would be a mistake to find authentically prefigurative ciphers of redemption in their actions, which are those of deluded, ignorant, desperate people and nothing more. 
Q. Can we see any sort of progressive, revolutionary or redemptive element, in this whole mess of blood bath? Can we anyhow read this other than being antiwest or a complicated anti-imperialist movement? Can you see a misguided revolutionary energy in all these violent efforts?

A. It is very problematic to posit a free-floating supply of "revolutionary energy" that can be correctly or incorrectly, progressively or regressively, directed. Are we talking about what Durkheim would have called primitive religious "effervescence" or what Nietzsche would have seen as the resentment of those who are weak and seek revenge for their fate? Are we talking about some Freudian oedipal rebellion against authority or Bataille's "general economy" of excess and transgression? I am sure that explanations for the pathologies we are witnessing-and I use that term advisedly-will be complex and over-determined, with many causes, some long-term, others proximate, playing a role. Lacking any serious expertise, I am reluctant to guess at what they might be.

Q. Resorting 'redemptive' violence reminds me Walter Benjamin's bet on WWI, as an opportunity for cleansing the world, and simplifying it through destruction. Is it an over-statement? A cleansing destruction idea frequently was popping up both in Critical thinkers and obviously more in its natural habitat; among right wing thinkers such as Carl Schmitt, surrealists, and eventually fascists. Do you see a resemblance between first decades of last century and today, in this sense? How did violence become a hope, yet again?

A. The passage to which you refer - the final aphorism of Benjamin's OneWay Street, "To the Planetarium" - is indeed one of the most controversial of his entire oeuvre. He adopts an apocalyptic rhetoric to interpret the war as a misguided attempt to transform the world in radical ways, restoring the ecstatic oneness with the cosmos lost in modern technological society. What he calls the "wooing of the cosmos" can only happen by pursuing a non-dominating version of technology, but it was undermined by capitalism: "Because the lust for profit of the ruling class sought satisfaction through it, technology betrayed man and turned the bridal bed into a bloodbath." It is hard to know what to make of these claims. Restoring harmonious oneness with the cosmos seems to me a pretty silly fantasy, and I am not sure if Benjamin really had any sense of how technology, even at its least dominating, was going to accomplish this utopian end. Benjamin, as you say, shared with some of the more dangerous theorists of $20^{\text {th }}$ century political theory 
a weakness for the purging powers of violence, which somehow was supposed to be the midwife of a better world. We know that it didn't turn out that way. As for blaming the failure on capitalism, this too is an empty explanation. Although some people did profiteer, the lust for economic profit was not a powerful cause of the war. In fact, the benefits of capitalist free trade were supposed to make war impossible because it would disrupt the global economy, as of course it did. All in all, I don't think this aphorism shows Benjamin at his most insightful.

Q. Attacking to French satirical magazine, Charlie Hebdo, dangerously open the debate for free speech, and its limits (mostly towards racism). How would you perceive the debates over free speech in this particular instance?

A. The debate over free speech and its limits has raged for centuries, at least since the acts of toleration that ended Christian wars of religion in the West. One thing that we have learned is that it is not absolute, but precisely where to draw the line is always very difficult to decide. At times, it has been too restrictive and the general trend has been towards greater and greater openness to controversial, transgressive and even offensive speech. But we have also learned that speech has a performative power, the ability to make something happen, which is more than just the expression of an opinion. In the case of what we call "hate speech," penalties should be paid for saying something hurtful and offensive. What the penalty might be, however, is anything but clear, although it certainly is not the one meted out by the killers in Paris.

About Charlie Hebdo, I don't have any sympathy whatsoever with the horrible penalty that their editors and cartoonists paid, the loss of their lives. For such a deed there can be no justification whatsoever. But my feeling is that if you take free speech as having a performative as well as expressive quality, as producing an intended outcome and having an impact in the world, and you take what they were doing in the magazine, not simply as expression of their beliefs or opinion, then free speech can be challenged, even curtailed to prevent the objectionable practical implications of what they are saying. Crying 'fire!' in a crowded theatre is not considered protected free speech, because it produces a panic, maybe even death. So there is no absolute claim to free speech under all circumstances. To be sure, one has to be careful to defend the right to speak freely, even to insult people, be offensive or even obscene, at least under certain circumstances. But it also should be recognized that speech acts 
can and do have consequences, for speech always occurs in an intersubjective context. It is not just my speaking to vent my thoughts; it is that I am speaking to somebody, either in particular or in general.

It is for this reason that in United States we have legal hate speech constraints, penalizing people for defaming others on the basis of race, gender, sexual orientation, religion and the like. In the classroom, where I have the special power of a teacher, I have to be particularly careful that I can 't insult a student in these ways. This prohibition is more than just what is sometimes belittled as "political correctness;" it is an acknowledgment that speech can do injury to vulnerable people and bigotry cannot hide behind the shield of an absolute defense of free speech, no matter the context.

I think one has to recognize that what these cartoons were doing was in some sense performatively problematic. Now, as I said before, the penalty to be paid must be decided through legal means in a court of law or perhaps in the larger court of public opinion, where bigots are ostracized and their hate speech decried. It is certainly not decided by murderous fanatics who claim to be administering their own form of extreme justice through violence. Not only does the punishment not fit the crime, but the result is entirely counter-productive, producing mass sympathy for those who did the insulting in the first place. And of course, there is always the danger that insults are merely excuses to justify violence that has other causes. The accompanying slaughter of innocent victims at the Kosher supermarket in Paris-people whose only crime was that they were Jewish-shows that the murderers were motivated by another, more sinister agenda than defending the honor of the Prophet.

Q. How about considering this in the context of a well-established satire tradition in France?

A. Another point that's very important to make is that in France there is a great tradition of attacking religion, often through scurrilous cartoons, which began in the $18^{\text {th }}$ century during the Enlightenment. When the Catholic Church was a close ally of the ancien regime absolute monarchy, to attack the latter meant also criticizing the authority of the former. In what came to be called the unity of throne and altar, the Catholic Church and the French monarchy reinforced each other's power, and clerics served as extensions of state power and were part of the ruling 
elite. When you mocked the French Catholic Church in the $18^{\text {th }}$ century, you were attacking all the entrenched institutions of power, including the absolutist state and the aristocracy, although of course there were also free-thinking libertines and materialist atheists who sought to discredit religion of any kind, no matter its connection with power.

In the $19^{\text {th }}$ century, there continued a tradition of mocking religion, but now with a difference. Although the Third Republic did fight a battle against the residual power of the Church, which sought to bring back some version of the ancien regime, there were new targets of mockery, in particular the Jews. In many anti-Semitic journals, Jews were depicted in scurrilous, obscene and insulting cartoons and writings. Culminating in the Dreyfus Affair, in which a Jewish army officer was falsely accused of treason, Jews were scapegoated as traitors to the French nation. The difference from the $18^{\text {th }}$ century, of course, was that unlike the Catholic clergy in the $18^{\text {th }}$ century, Jews were not intimately tied to the reigning powers of the state. Some anti-Semites, to be sure, were deluded into thinking Jews had extraordinary powers behind the scenes, but no serious historian would now back up this unfounded assertion. So when Judaism and the Jews were mocked and insulted, they were not legitimate targets of those who were oppressed by the unity of throne and alter (or synagogue). The victims were marginalized and relatively powerless in French society.

In the case of Muslims in contemporary France, it seems to me they are like the Jews in $19^{\text {th }}$ century. They are not people who are associated with the power of the state. They don't dominate the society in the way the Catholic Church in the Ancien Régime did. To attack Islam or to attack Judaism is not to attack the centralized power of an oppressive state, the way attacking Catholicism was in $18^{\text {th }}$ century. It is wrong to kick a group that's down by mocking their culture and religion, which only makes them feel more alienated, disgraced and abused. In those cases, however, where a dominant religion may be harnessed by a repressive state to stigmatize and discriminate against minorities, then it is legitimate to call that misuse of religion into question. But one has to be very careful not to do so by mocking the religion in general, defaming its prophets or saints, but rather only by challenging its current abuse of power. No great religion can be reduced to the dreadful uses to which some of its cynical or deluded adherents put it. 
Q. But Charlie Hebdo was also mocking ultra nationalist French figures like Marine Le Pen. They were also mocking xenophobia... They were like anarchists. They were mocking everything and meanwhile...

A. I'm sure there was a whole spectrum of targets. Like some of the anarchists in the U.S. who just want to smash property to release their freefloating hostility to any authority, they were what we ironically call "equal opportunity" mockers. But you have to be more precise in your choice of victims and realize that some people and institutions deserve to be mocked and need to have their power challenged, while there are other people and groups who are victims and already suffer mockery in their daily lives. In the U.S. I might make jokes about say, WASPS (White Anglo-Saxon Protestants), who have long been the mainstays of our power elite, but I could never in good conscience make jokes about Mexican Americans or Blacks or Muslims or gays. You know a person is not politically aware of the fact that thatpower differentials exist in a society if they mock everybody indiscriminately.

Another issue, of course, is how one responds to insults or offensive remarks and images. You can respond with rage and strike back, or decide that the offenders are idiots, whose insults shouldn't be dignified with a response. The latter thwarts the performative intention to hurt and injure the victim by, as we say, "turning the other cheek." Instead of anger, it expresses pity for the person who does the insulting, who are in some ways damaged and unable to express their ideas in rational ways. Like non-violence in general, it is often far more effective than contributing to a cycle of revenge that is hard to end.

Q. Meanwhile I knew Charlie Hebdo since in the past they collaborated with a Turkish cartoon magazine, Leman and published a joint issue. So I am familiar with their cartoons and satirical stance. Bu then I remember, a few years ago there were these controversial Danish illustrations. Apart from everything, they were all sharing the great sin of being not funny as cartoons. And I remember they immediately remind me anti-Semitic cartoons.

A. Well, I think that's the lamentable tradition.

Q. Yes, there were no jokes with these cartoons. Just ugly faced oriental people.

A. This kind of continuity is, I agree, appalling. There is a fungibility of targets in which virtually the same things can be said against blacks, 
against Jews, against Muslims, against gays, against whatever the stigmatized group might be. You almost always can find variations of the same theme: they are dirty, they are animals, they are sexually hyperactive, they are ugly, they are clannish, etc. Whatever the accusation may be it is easily transferable to a new victim.

Q. That's right. Very similar to 1930's Jewish cartoons...

A. In fact, it is the same thing.

Q. But then let's put Danish cartoons apart. Charlie Hebdo was attacking equally to everybody. Well they also published these Danish cartoons but they do it for the sake of free speech. The thing about the Danish cartoons, there were no other sorts of cartoons, juxtaposed with these ones. They were mere insults. Not only insults to fundamentalism but insults to a group of people. Shouldn't there be at least a distinction between Danish cartoons and this sort of anarchist stance?

A. I haven't studied the motivations behind the cartoons in every case. So I think it's probably true that sometimes they sought to make a particular political point, for example, to be little immigrants for threatening the hegemonic way of life. In other cases, however, they merely expressed a kind of adolescent, anarchistic desire just to be provocative for the sake of provocation. And so whatever the taboo might be, they'll break it in order to gain attention by being outrageous and transgressive. But even these immature insults for their own sake shouldn't be understood as a justification for violent responses by those they may insult.

Recently the owner of a basketball team, the Los Angeles Clippers, was caught on a private tape, talking to his girlfriend, saying demeaning things about blacks. Now this was not a public statement meant to provoke. But it became public because his girlfriend was upset with him and leaked the tape. And of course many of the players in his team and in the NBA in general are black. And so they were justifiably furious. The result was that he was forced by public opinion and by the league---that is, other team owners-- to sell his team. He was no longer considered a credible owner because of his racist attitudes. But they didn't then take him to the middle of Staples Arena in Los Angeles and behead him. He wasn't even put in jail, although he paid a very serious penalty. 
I think society has to maintain civility and be able to penalize in ways besides through violence or coercion the people who deliberately insult, offend, provoke, and engage in "hate speech." This is especially the case when they do so to groups or individuals who are relatively powerless in the society. But there is also a counter-imperative to maintain the right to say controversial, uncomfortable, dissenting things and not be censored or worse. I have long been a member of the American Civil Liberties Union, which defends, often in an absolutist way, the right to free speech. As in any free society, there are often competing imperatives which prevent us from having a simple rule that we can apply in all circumstances. Political judgment is precisely the ability to know how to balance them in individual cases.

Q. How about this cartoon, mocking the ISIS leader Al-Baghdadi?

A. To speak briefly, it seems to be entirely appropriate. It shows the absurdity of a religious fanatic, who hides his murderous impulses behind the cloak of a great religion, and in so doing demeans the very religion he pretends to be defending, wishing everyone good health. It reminds me of the campaigns for "racial hygiene" advocated by the Nazis, while they were committing genocide against the Jews.

What I like about the cartoon is that it avoids belittling the religion that Al-Baghdadi claims to represent. Even if you may think all religions are nonsense, in the manner of the 18th-century libertines, it is wrong to insult and mock a believer. You may argue or try to persuade them of their errors-and of course you have the obligation then to listen to their counter-arguments-but you don't have the right to demean them. Not only does doing so create the danger of crying "fire" in a crowded theater, but also leaves you vulnerable to being caught in the stampede.

Q. When it comes to humor, satire and cartoons, those limits could be blurry.

A. It is very typical to argue that those who are offended "can't take a joke," but you shouldn't always hide behind humor. We have a number of American comedians who are very gifted at delivering humorous insults, sometimes playing off obnoxious stereotypes. They say outrageous things in the explicit context of humor that they would never be able to say in a normal conversation without being punched in the 
mouth. But because there is a shared awareness that their aggression is not meant seriously, the objects of their attack will laugh along with it and will accept it as a part of the game that's being played. But it's a very delicate game, which sometimes goes beyond a certain threshold, and what they say stops being funny. Suddenly no one's laughing. The sting behind the jest becomes too painful to endure and the game breaks down. There are also jokes which are inclusive, in which everyone can join in the laughter, and jokes which are exclusive, where one group is being mocked or demeaned.

When sexism became a sensitive issue in United States in the 1970's, jokes at the expense of women suddenly became less funny and the boundaries of what was acceptable humor changed. The same has now happened with jokes about gays and other sexual minorities. Social pressure and enhanced sensitivity meant greater awareness that some jokes were simply inappropriate and no longer able to solicit a laugh. But however justified the limits on such humor might be, it is also important to resist another type of limit, that placed by people in power who are unhappy about being the object of mockery. A government that tries to censor jokes about its leaders or their policies is a government that is inherently weak and unable to learn from the criticisms that such humor often contains. A healthy polity is one in which authority figures of all kinds can endure being lampooned, satirized and knocked off their pedestals.

Q. Would you believe prophecy of a historian? At least they are allowed to make speculations. From here, where are we heading?

A. I have no clue. I never ceased being amazed by what the world has in store for us.

February 2015, Berkeley 